\title{
The poor health of deep-water species in the context of fishing activity and a warming climate: will populations of Molva species rebuild or collapse?
}

\author{
Lloret Josep 1, *, Serrat Alba 1, Pórðarson Guð̃mundur 2, Helle Kristin ${ }^{3}$, Jadaud Angelique ${ }^{4}$, \\ Bruno Isabel ${ }^{5}$, Ordines Francesc ${ }^{6}$, Sartor Paolo ${ }^{7}$, Carbonara Pierluigi ${ }^{8}$, Rätz Hans-Joachim ${ }^{9}$
}

1 University of Girona; Institute of Aquatic Ecology; Girona Catalonia, Spain

2 Marine and Freshwater Research Institute; Reykjavík, Iceland

3 Institute of Marine Research; Bergen,Norway

4 MARBEC, Ifremer, Université de Montpellier, CNRS, IRD; Sète, France

${ }^{5}$ Centro Oceanográfico de Vigo, Instituto Español de Oceanografía; Vigo ,Spain

${ }^{6}$ Centre Oceanogràfic de Balears, Instituto Español de Oceanografía; Palma de Mallorca, Spain

${ }^{7}$ CIBM Consorzio per il Centro Internuniversitario di Biologia Marina ed Ecologia Applicata "G. Bacci"; Livorno , Italy

${ }^{8}$ COISPA Tecnologia \& Ricerca, Stazione Sperimentale per lo Studio delle Risorse del Mare; Bari, Italy

9 Thünen Institut; Bremerhaven, Germany

* Corresponding author : Josep Lloret, email address : josep.lloret@udg.edu

\begin{abstract}
:
Many deep-water fish populations, being k-selected species, have little resilience to overexploitation and may be at serious risk of depletion as a consequence. Sea warming represents an additional threat. In this study, the condition, or health, of several populations of common ling (Molva molva), blue ling (M. dypterygia) and Mediterranean or Spanish ling (M. macrophthalma) inhabiting different areas in the North Atlantic and the Mediterranean was evaluated, in order to shed light on the challenges these deep water species are facing in the context of fishing activity and a warming climate. The data on the condition of Molva populations which we analyze here has been complemented with data on abundance and, for the southernmost species (Mediterranean ling), with two other health indicators (parasitism and hepatosomatic index). Despite some exceptions (e.g., common ling in Icelandic waters), this study shows that the condition of many populations of Molva species in the Northeastern Atlantic and the Mediterranean Sea has worsened, a trend which, in recent decades, has usually been found to be accompanied by a decline in their abundance. In addition, the poor health status of most of the populations of common ling, blue ling and Mediterranean ling considered in this analysis points to a lower sustainability of these populations in the future. Overall, the health status and abundance of Molva populations in the Northeastern Atlantic and the Mediterranean suggest that only some populations located in the north Atlantic may be able to rebuild, whereas the populations in southern North Atlantic and the Mediterranean, which are probably most at risk from sea warming, are facing serious difficulties in doing so. In the context of fisheries and global warming, our results strongly indicate that management bodies need to consider the health status of many of the populations of Molva species, particularly in southern European waters, before implementing their decisions.
\end{abstract}


Keywords : Condition, parasitism, reproduction, deep-water fish, fisheries, sea warming 


\section{INTRODUCTION}

Many deep-water fish stocks have been reported to be at serious risk of depletion (Morato et al., 2006; Bailey et al., 2009). Most deep-water fish species exhibit clear "K-selected" life-history characteristics, markedly different from most species inhabiting the continental shelf, the upper continental slope or the open pelagic ocean ecosystem (Koslow et al., 2000); they usually have high longevity, slow growth, late maturity, and low fecundity, and many also aggregate on restricted topographic features such as seamounts or canyons that constitute fragile habitats because of the particular benthic fauna inhabiting these deep areas (Koslow et al., 2000, Roberts, 2002, Clarke et al., 2003; Morato et al., 2006). As a consequence, many deep-water fish populations are notably unproductive, highly vulnerable to overfishing, and have potentially little resilience to overexploitation (Koslow et al., 2000, Roberts, 2002; Large et al., 2003). On the whole, deep-water fish populations in the northeastern Atlantic decreased significantly from 1970 onwards (Bailey et al., 2009), and in the Mediterranean Sea some deep water stocks have shown symptoms of overexploitation (IUCN, 2004). Furthermore, sea warming, which has been associated with declines in cold water species and increases in warm water species in these regions (see e.g., Perry et al., 2005; Petitgas et al., 2012; Lloret et al., 2015), may pose a complementary threat to some deep water stocks, and therefore further information on the impact of sea warming on these stocks is particularly needed. Assessing the vulnerability of fish and invertebrates to climate change is a high priority for fishery resource monitoring and management (e.g., Hare et al., 2016). Temperature is a dominant environmental driver for predicting pelagic fishery health and likely a strong driver in the benthic environment (Kavanaugh et al., 2017). However, little is yet known about how most deep-water fish communities change or adapt in response to anthropogenic disturbance or sea warming, and providing such information would greatly enhance our understanding of deep-water systems and the management of deep-water fisheries (Bailey et al., 2009). And yet, despite this bleak outlook for deep-sea stocks, the European Council Regulation (EU) 2018/2025 of 17 December 2018, which sets the fishing opportunities for 2019 and 2020 for EU fishing vessels for certain deep-sea fish stocks, only covers a few teleost species (Aphanopus carbo, Beryx spp., Coryphaenoides rupestris, Macrourus berglax and Pagellus bogaraveo). New studies are therefore urgently required to help justify appropriate local management plans and rebuilding actions aimed at avoiding the depletion of other deep water stocks. 
The three Molva species, i.e. common ling or ling (Molva molva [Linnaeus, 1758]), blue ling (M. dypterygia [Pennant, 1784]) and the Mediterranean or Spanish ling (M. macrophthalma [Rafinesque, 1810]) are deep water gadoids with K-selected life history characteristics (ICES 2015, Morato et al., 2006, Roberts, 2002, Large et al., 2003; Mecklenburg et al., 2018). The common ling is distributed in the North Atlantic and in some areas of the north-western Mediterranean Sea, usually at depths of up to 500 $\mathrm{m}$; blue ling is distributed in the North Atlantic, from southern Ireland to the Barents Sea and southeastern Greenland, usually at depths of up to $900 \mathrm{~m}$; and Mediterranean ling is found from southern Ireland to the Mediterranean Sea, usually at depths of up to $800 \mathrm{~m}$ (ICES, 2019; Serrano et al., 2011). These species have been exploited for decades or even, in some cases, for centuries, by European fleets (Bergstad and Hareide, 1996; ICES, 2014, 2015; Lloret et al., 2015). In the North Atlantic, common ling and blue ling are caught by longlines, gillnets and/or trawling (either targeted or bycatch, depending on the zone and gear), with the quantities taken by each fleet depending on the area and also the year which, in turn, depends on the fishing opportunities permitted for the fleet's main target species, which may be, for example, Atlantic cod, Gadus morhua (ICES, 2014, 2015, Bergstad and Hareide, 1996). In the Mediterranean, common ling is mainly caught and landed as bycatch by longliners, whereas Mediterranean ling is caught by longliners (large individuals) and trawling (small individuals) (Lloret $e t$ al., 2015).

There are several reports (ICES 2014, 2015, 2019) and scientific publications (Bergstad and Hariede, 1996; Poulsen et al. 2007; Lloret et al., 2015) indicating that the abundance of many populations of these three Molva species in European waters is, at present, lower than it was in the late $19^{\text {th }}$ or $20^{\text {th }}$ century centuries, when industrial or semi-industrial fisheries first began to operate. In the case of the common ling, although fisheries have exploited this species for centuries, a time-series of abundance indices from around 1970 onwards suggest significant declines in abundance of this species in many fishing areas (Poulsen, 2007; Bergstad and Hariede, 1996). For example, drastic declines were observed in catches of common ling in the North Sea, including Skaggerak and Kattegat between 1995 and 2005, when catches halved (Poulsen et al., 2007). Blue ling populations in the Northeast Atlantic were moderately exploited until the 1960s and 1970s. However, more intensive fishing throughout its range, but particularly in the spawning grounds, subsequently led to a collapse of populations during the late 1990s (Large et al. 2010). There is also some evidence that sea warming may be playing a role in the observed changes: the distribution of ling in the North Sea, for example, has shifted northward in response to sea warming (Perry et al., 2005). In the Mediterranean Sea, the abundance of the Mediterranean ling and common ling has also been found to be in decline in recent decades in a context of fishing pressure and sea warming (Lloret et al., 2015).

Although fish health can influence key population-level processes, particularly those dealing with natural mortality, reproduction and growth which, in turn, affect population productivity, little emphasis has been placed on how information on fish health can improve decision-making in the management of marine fisheries (Lloret et al., 2012). Furthermore, despite an increasing number of biological studies of Molva species over recent decades, knowledge on such an important biological trait as fish condition for these species remains limited. To address this issue, we have evaluated a number of condition indices of 
Molva species to be used as indicators of their physical health, and these could help explain the present state and future development of the populations in the North Atlantic and Mediterranean Sea. Hence, in this paper we analyze for the first time the evolution of the health status of Molva populations inhabiting areas with different fishing regimes and thermal conditions in the North Atlantic and the Mediterranean, in order to shed light on the challenges these deep water species are facing in the context of fishing activities and a warming climate. The analysis of the data on the condition of the populations has been complemented with an analysis of abundance data for Molva species in these areas, in order to obtain an overall picture of the current state of these populations, along with an evaluation of two other health indicators (parasitism and hepatosomatic index) for the southernmost species (Mediterranean ling).

\section{MATERIALS AND METHODS}

We combined various sets of information (biological data, fishery statistics, and scientific and grey literature) from different periods of time and subareas (Table 1) within the North Atlantic (ICES Subareas) and Mediterranean waters (GFCM Geographical Subareas, GSAs) in which the three species of the genus Molva are distributed, in order to obtain a general view of the status of the different populations

(Fig. 1). We did not capture or kill any animals for the purposes of this study; we used data already gathered from various fishing surveys conducted in previous years. All data come from fish that were already dead during the normal fishing process. There is some debate as to whether M. dypterygia and $M$. macrophthalma are, in fact, two distinct species, and some authorities identify them as two sub-species, Molva dypterygia dypterygia and M. dypterygia macrophthalma (Basson et al., 2001). In the present study, however, we shall assume them to be two distinct species.

\subsection{Le Cren's relative condition index}

Individual weight and lengths obtained from various surveys from different North Atlantic ICES subareas were used to assess the evolution of the Le Cren's relative condition index (Kn) of M. molva and $M$. dypterygia in the North Atlantic (data for M. macrophtalma in the North Atlantic was only available over a limited period of a few years and was therefore disregarded). This index measures the deviation of an individual from the average weight-at-length for the species in the respective sample (Lloret et al., 2014). It was computed as $\mathrm{Kn}=\mathrm{TW} / \mathrm{TWe}$, where TW is the total body weight of one fish and TWe is the estimated total body weight of that fish derived from the species weight-length relationship obtained from all the individuals sampled. The benchmark for $\mathrm{Kn}$ is 1 , i.e. fish above or below 1 are, respectively, in better or worse condition than the average individuals in the population. For each species, data from all the surveys of the different subareas were pooled together to evaluate the relative condition. Data were provided by different research institutions: Institute of Marine Research (Norway), Marine and Freshwater Research Institute (Iceland), Institute for Sea Fisheries-Thünen Institute (Germany), Instituto Español de Oceanografía (Spain) and ICES (DATRAS database). During the data analyses, some ICES subareas were pooled together for two reasons: (i) not all subareas had enough data to run the analyses 
and (ii), the geographical origin of some samples was not reported according to standard ICES geographical subareas, but with a variety of nomenclatures (e.g. Arctic Sea, North Sea, etc). Furthermore, the identification of Molva populations is still uncertain (ICES 2019). Therefore, we grouped the available data based on geographical proximity and data availability, resulting in five ICES subareas for the North Atlantic (Fig 1): North-West Norwegian waters (subarea 2), North Sea (subarea 4), Iceland (Division 5a), Ireland (subareas 6 and 7 together), and Greenland (subarea 14). In the Mediterranean, the GFCM subareas from which data were obtained were: Balearic Islands (GSA5), Northern Spain (GSA 6), Gulf of Lion (GSA7), Corsica (GSA 8); Ligurian Sea and northern Tyrrhenian Sea (GSA 9); and Southern and Central Tyrrhenian Sea (GSA 10).

To assess and compare the temporal trend of condition among these areas, Generalized Linear Mixed Models (GLMM) were built for each Molva species. Regarding M. dypterygia, the model included data from 1960 to 2014, while the variation in condition of M. Molva was analyzed using data from 2000 to 2016. For each species, the Kn was incorporated in the models as the response variable; the year (Y) and the subarea $(Z)$ of capture, as well as their first order interaction, were included as fixed explanatory variables. Because the data comes from several trawl surveys which were run by different organizations from different countries, the sampling could not be performed on the same month every year and in every area. Thus, the influence of the month $(\mathrm{M})$ of capture was accounted for by including it in the model as a random factor with uncorrelated random intercepts and slopes. Although the depth of capture, sex and the gonad development stage could also explain some of the variation in condition, these parameters were not taken into account here because the data were only available for a few individuals. Starting from the most complex model including all the aforementioned parameters, the non-significant variables were dropped in a stepwise backward procedure. Models were compared using Aikake's Information Criteria (AIC). The model with the lowest AIC was considered to be the best fit model (see Supplementary Table S1). Models showing differences in AIC values lower than two were considered to be equivalent (Burnham and Anderson, 2002). The GLMMs were fitted by maximizing the log-likelihood using the Laplace approximation, and computed using a loglink function and gamma family using the lme4 package (Bates et al 2014) in $\mathrm{R}$ version 3.5.3 ( $\mathrm{R}$ Core Team, 2019). The marginal $\mathrm{R} 2\left(\mathrm{R} 2_{\mathrm{m}}\right)$ and the conditional $\mathrm{R} 2\left(\mathrm{R} 2_{\mathrm{c}}\right)$ were calculated for the best fit model (a GLMM) using the MuMIn package (Barton, 2013). Any differences between the corresponding $\mathrm{R} 2_{\mathrm{m}}$ and $\mathrm{R} 2_{\mathrm{c}}$ values reflect how much variability is due to random effects (Nakagawa and Schielzeth, 2013).

In addition, for M. molva taken from ICES subarea 4, where the data were available for a longer time period (1950-2016), the Kn was recalculated based exclusively on the samples from this area and its variation was modeled for the whole period. Model inference and comparison were performed as described above, with $\mathrm{Kn}$ as the response variable, $\mathrm{Y}$ as an explanatory fixed effect and $\mathrm{M}$ as a random effect, with an uncorrelated random intercept and slope and also with a random intercept with fixed mean. The $R 2_{m}$ and $R 2_{c}$ values of each model were computed. The model with the lowest AIC value was selected (Supplementary Table S1).

\subsection{Average individual weights}


Individual weights were not available for the Mediterranean ling in the Mediterranean Sea. Instead, we used information obtained during the MEDITS experimental trawl surveys (AAVV, 2017; Spedicato et al., 2019), performed in France, Spain and Italy from 1994 which provided the annual average individual total weight in the population. This was used as a size-based indicator of the status of the population (Jai Shin et al., 2005). Data were provided by different research institutions: IFREMER (Fisheries Information System -SIH) for France (GSA7 and 8), IEO for Spain (GSAs 5 and 6), CIBM and COISPA for Italy (GSAs 9 and 10).

\subsection{Hepatosomatic index and parasitism}

For many demersal species such as gadoids, energy stores mostly comprise lipid stored in their liver and therefore the hepatosomatic index (HSI) is a more accurate measure of their condition than simple morphometric indicators (Lloret et al., 2012). On the other hand, parasitic infection can also be an important health indicator, and has been shown to affect natural mortality, growth, fecundity, and recruitment in gadoid species, such as European hake (Merluccius merluccius) in the Mediterranean (Ferrer-Maza et al., 2014; Carbonara et al., 2019). Thus, in the case of the northern Catalan Coast (Spain, NW Mediterranean), we gathered data on liver weights and parasitism of M. macrophthalma to gain further insight into the health status of this population. From November 2010 to April 2011, a total of 162 females and 20 males of M. macrophthalma were collected (84\% of samples from commercial trawlers and $16 \%$ from longline catches) at two ports in the northern GSA6/southern GSA7 areas of the NW Mediterranean. For each individual, total body length (TL) was measured (rounded down to the nearest $\mathrm{cm})$, and then eviscerated body weight (EW), liver weight (LW), and gonad weight $(\mathrm{GW})$ were recorded $(+0.1 \mathrm{~g})$. These values enabled us to calculate the hepatosomatic index (HSI) and the gonadosomatic index $(\mathrm{GSI})$ as follows: HSI $=(\mathrm{LW} / \mathrm{EW}) * 100$, and GSI $=(\mathrm{GW} / \mathrm{EW}) * 100$. The sex and maturity stage of individuals was determined via macroscopic inspection of gonads, following Lloret et al. (2015). In addition, 87 individuals were examined for metazoan parasites, following the procedure given in FerrerMaza et al. (2014) and Serrat et al. (2019).

\subsection{Abundance}

Several indicators were analyzed to evaluate the recent trends (i.e., from 1950 onwards) in abundance of the three Molva species: landings, catch per unit effort (CPUE) time-series from both commercial sources and scientific surveys, and stock exploitation status. In the North Atlantic, information on landings of the Molva species was obtained using FishStatJ (a software application for fishery and aquaculture statistical time series provided by the FAO), whereas, for the other areas, information on commercial CPUE and research survey abundance series were obtained from recent ICES WGDEEP reports and the IFREMER SIH database. Unfortunately, FishStatJ records of landings of Mediterranean ling in the Mediterranean cover only a very few years and only in Spain, and therefore we mainly used survey abundance indices (number of individuals $/ \mathrm{Km}^{2}$ ) from Spanish, French and Italian MEDITS trawl surveys, from 1994 onwards, provided by IFREMER, IEO, COISPA and CIBM (see AAVV, 2017 and Spedicato et al., 2019 for specifications of the surveys) and a commercial CPUE series from a fishing port in the northern Catalan Sea (NW Mediterranean) where there is a bottom longline fishery operating within GSA7 (Gulf 
of Lions).

\section{RESULTS}

\subsection{Common ling (Molva molva) in the North Atlantic and the Mediterranean}

The best-fit model for common ling included the year (Y), the subarea $(\mathrm{Z})$ and their first order interaction (Table 2). The relative condition index ( $\mathrm{Kn}$ ) varied significantly along years and between areas (Table 2). The significant interaction between $\mathrm{Y}$ and $\mathrm{Z}$ indicated that the temporal variation of the mean condition differed between areas (Table 2). The inclusion of the random effect - month of capture, $\mathrm{M}$ - in the model increased the proportion of variance explained by the model, and, evidenced the fact that $\mathrm{M}$, which may differ between one subarea and another, has an influence on the variation in the condition index (Table 2).

From 2000 to 2016, the mean condition index, Kn, increased significantly, and almost in parallel, in subareas 2 and 5, with higher mean values in subarea 2 (Figure 2). In subareas 4, 6, 7 and 14, the Kn showed a decreasing trend over time, particularly strong in subarea 14; among these, subarea 4 showed the highest mean Kn values (Figure 2). The longer temporal series available for subarea 4 (from 1959 to 2016) also showed a downward trend in Kn over time (Figure 3) with the month of capture included as a random effect, which increased the proportion of variance explained by the model (Supplementary Table S2).

Although the populations of common ling that have been assessed (Supplementary Table S3) are regarded as being in a good state or fished sustainably (i.e., the estimated fishing mortality is below the $\mathrm{F}_{\mathrm{MSY}}$ ), and commercial and survey CPUE series generally show a stable or upward trend (except for subareas 7 and 8, which show decreasing abundance and biomass), the data we have gathered on landings show a very different pattern: in the southern areas (data from France, Spain and Portugal), landings decreased sharply from the 1970s onwards, with values in 2016-2018 being very low and comparable to the 1950s (Figure 4), whereas in the northern areas (rest of countries), landings have fluctuated over the period 1950s-2018 without any clear trend (Figure 4). In some northern areas, such as Division 5a, increasing biomass and/or recruitment has been observed in recent years (Supplementary Table S3). In the Mediterranean, this species disappeared from the catch in GSA 7 (the main area of distribution of this species) in the 2010s (Supplementary Table S3).

\subsection{Blue ling (Molva dypterygia) in the North Atlantic}

The best-fit model for blue ling (Table 3) included the year (Y), the subarea (Z) and their first order interaction. The relative condition index $(\mathrm{Kn})$ varied significantly along years and between areas (Table 3). The significant interaction between $\mathrm{Y}$ and $\mathrm{Z}$ indicated that the temporal variation of the mean condition differed between areas (Table 3). As in the case of common ling, the inclusion of the random effect (M) in the model increased the proportion of variance explained (Table 3). The mean Kn of blue ling showed a positive trend in subarea 2 from 1959 to 2015 (Figure 5), while in subareas 4 and 14, the 
trend was negative and no trend was observed in subarea 5 in recent years (Figure 5). Although the overall trend in subareas 6+7 was negative, a positive trend can be detected from 1974 to 1986 with a visual exploration of the data, after which there is a lack of data for 20 years followed by a negative trend from 2007 to 2013 (Figure 5).

In Division 3a and subareas 4, 6, 7, 8, 9, 10, 12, 14 (Supplementary Table S3), the spawning stock

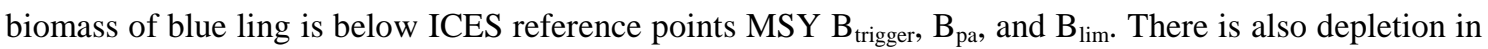
subarea 2. Since 2010, there has been a decline in commercial and survey CPUE series in subarea 14 and Division 5a and landings in all areas have decreased severely from the early 1980s onwards, with the values for 2016-2018 being the lowest values of the time series, similar to the levels in the 1950s (Supplementary Table S3).

\subsection{Mediterranean ling (Molva macrophthalma) in the North Atlantic and the Mediterranean}

The average weight of Mediterranean ling in GSAs 7, 8, 9 and 10 declined over the study period, although only the downward trend in GSA 7 was significant (Spearman's Rho; $p<0.01$ ). Meanwhile, there was a slightly upward - but insignificant $(\mathrm{P}>0.01)$ - trend in the GSAs 5 and 6 (Fig. 6).

Regarding the biological sampling in the northern Catalan coast (within GSA 6 and GSA7), the analysis reveals that immature fish comprise up to $61 \%$ of the individuals sampled by trawling, with the remaining 39\% being mature. In stark contrast, samples from longlines comprised 79\% mature fish and $21 \%$ immature. Fig. 7 shows the relationship of maturity with HSI and GSI values and the prevalence of parasites. HSI values increase as gonads develop from the immature stage, reaching maximum values before spawning (in the maturing and spawning capable stages, when GSI values also reach maximum).

The percentage of parasitized fish increases as they progress through the reproductive cycle. Immature individuals show the lowest proportions of prevalence of parasites $(<20 \%$ of fish infected) whereas individuals in regenerating and regressing stages show the highest prevalence of parasites ( $>70 \%$ of fish infected). Overall, $38 \%$ of all fish presented parasites.

In the North Atlantic, landings of Mediterranean ling have decreased sharply from the late 1970s and early 1980s onwards, with the lowest values of the time series occurring during 2016-2018 (Fig 4); CPUE time series data from trawl surveys also show decreasing abundance and biomass since 2014 in $7 \mathrm{c}, \mathrm{k}$ (Supplementary Table S3). In the Mediterranean Sea, survey CPUE series show decreasing abundance and biomass in GSA 9 and 10 and decreasing biomass in GSA 7, whereas no clear trends in abundance and biomass were found in the rest of the GSAs (Supplementary Table S3). The CPUE time series of larger individuals in the NW Mediterranean, however, have shown a decrease since the 2000s (Supplementary Table S3).

\section{DISCUSSION}


Despite the heterogeneity of data and time periods from species to species and from area to area, the combined information given here provides a good general picture of the status of the Molva populations. This study shows that the condition of a number of populations of Molva species in the Northern Atlantic and the Mediterranean Sea has worsened, a trend that has been generally accompanied by a decline in their abundance in recent decades. Specifically, of those studied in the North Atlantic, three out of five common ling and three of out five blue ling populations showed a worsening in condition since the mid1990s or the 2000s as did four out of six Mediterranean ling populations in the Mediterranean. Only a few populations appeared to be improving: common ling and blue ling in ICES Subareas 2 (Northeast Arctic) and 5a (Iceland) and Mediterranean ling in GSAs 5 and 6 (although blue ling in the Northeast Arctic is depleted according to Helle et al., 2018). The fact that more than half of the populations investigated are in poor condition strongly indicates a lower sustainability of these populations in the future. In addition, since the 1980s, blue ling and Mediterranean ling have declined in abundance in the North Atlantic in general, and common ling has declined in abundance in more southern areas of the North Atlantic.

In the North Atlantic, common ling and blue ling populations show a trend of declining $\mathrm{Kn}$ in the 2000s-2010s period except in ICES subareas 2 and 5a, where a positive trend is observed. The decline in $\mathrm{Kn}$ is particularly notable in ICES subarea 4, which happens to have the longest available time series of Kn values, beginning in the late 1950s. In the Mediterranean Sea, the average individual weight of the Mediterranean ling is decreasing in areas where the largest individuals are found (GSAs 7, 8, 9 and 10) although in GSAs 5 and 6, where individuals are generally smaller, the average individual weight is either stable or increasing. Several studies have described a positive correlation between larvae survival and female size (Trippel et al., 1997; Vallin and Nissling, 2000; Domínguez-Petit et al., 2010; Carbonara et al., 2015), suggesting a qualitative/quantitative maternal effect on the reproductive fitness in a number of different species. Therefore, the decreasing average size of Mediterranean ling in several GSAs could represent a further critical element in the conservation prospects for this species in the Mediterranean basin. Furthermore, the biological sampling carried out in GSAs 6 and 7 shows that the adult part of the population, decreasing in abundance, is highly parasitized compared to immature individuals. In other words, there appears to be a fragile and declining population of adults in relatively bad condition. The poorer condition (indicated by a lower liver index) of juveniles compared to adults is a normal feature in fish populations (Lloret et al., 2014), but in this case the decline in adults reveals the poorer overall status of a population dominated by juvenile fish with lower energy reserves.

Although in many northern Atlantic areas, from the British Isles to the north around Iceland and the Faroe Islands, the decline in landings and abundance of Molva populations seems to have slowed down or even reversed in the last two decades (Bergstad and Hareide, 1996; ICES 2015, 2019; Lorance et al., 2010), our results indicate that some northern populations (e.g. blue ling in Norway), as well as southern populations of common ling, blue ling and Mediterranean ling, from the British Islands to the south including the Mediterranean Sea, are still in a very poor and depleted status.

Even for populations such as common ling and blue ling in Icelandic and Faroese waters which, at present, appear to be in good health according to assessments made by ICES (2019), it should be noted 
that the time series recording abundance and biological parameters were usually initiated in the 1950s and 1960s; and if we compare such data with historical estimates (from before this period), new perspectives on the scale of past declines emerge (Poulsen et al., 2017). Although CPUE for common ling in the North Sea has been increasing in recent years and assessments indicate that populations are being fished sustainably (ICES, 2019), the features of these populations in the 2000s (low abundance and smaller sizes) compared those of the $19^{\text {th }}$ and $20^{\text {th }}$ centuries are consistent with symptoms of overexploitation. For example, according to Petersen (1890) and Poulsen et al. (2017), common ling caught by the longliners in the late 19th century and early 20th century in the North Sea were larger (TL between 89 and $125 \mathrm{~cm}$ ) than those in the range of a modal size group of common ling caught between 1976 and 1995 (TL between 60 and $95 \mathrm{~cm}$ ). In the western English Channel, a reduction in the mean length and/or the mass of common ling over the period 1911-2007 was also found (Genner et al., 2010). Similarly, between 1976 and 1995, the mean length of common ling caught by Norwegian longliners in several North Atlantic areas decreased, specifically from $87.0 \mathrm{~cm}$ to $81.1 \mathrm{~cm}$ in ICES Division 4a, and from $80.0 \mathrm{~cm}$ to $73.7 \mathrm{~cm}$ in ICES Division 6a (Bergstad et al., 1996).

Molva species are known to reach maturity at large body sizes (late maturity): length at 50\% maturity is estimated to be between $60 \mathrm{~cm}$ and $75 \mathrm{~cm}$ for common ling (ICES, 2019); between 77 and $85 \mathrm{~cm}$ for blue ling; (Mangússon et al., 1997; ICES, 2019), and between $58 \mathrm{~cm}$ and $67 \mathrm{~cm}$ for Mediterranean ling (Miret and Vera, 2011). Hence, a reduction in the mean size of Molva species will more likely exacerbate their vulnerability to overfishing by impacting on the reproductive potential of whole populations. However, not all species and stocks have followed the same pattern. For example, the mean sizes of blue ling caught by trawlers in the early 1980s were $93.3 \mathrm{~cm}$ in Icelandic waters (ICES Division 5a; Magnusson, 1982) and $88.3 \mathrm{~cm}$ in East Greenland (ICES Division 14; Reinsch, 1981); the figures recorded in the period 2015-2018 - for East Greenland and Iceland combined - show an increase in mean size to between 96 and $101 \mathrm{~cm}$ (ICES, 2019). Also, in the Faroes (ICES Division 5b), there is no evidence in the catch of trawlers of a decline in the mean length of blue ling: $101 \mathrm{~cm}$ in the early $1980 \mathrm{~s}$ and between 99.5 and $102.2 \mathrm{~cm}$ in the period 2015-2018 (ICES, 2019). Nevertheless, caution must be taken when comparing current length-distribution data with historical records due to the changes over time in both fishing patterns and gear type used, as well as the fact that data from different North Atlantic areas have often been combined in recent stock assessment reports (current stock units comprise individual ICES Sub-areas or groups of them and, occasionally, ICES Divisions, see e.g. ICES, 2019).

Having said that, in areas such as Iceland, the North Sea, Western British Isles, Northwest of Scotland, Swedish waters, Skaggerak and Kattegat, West of France, and West of the Iberian Peninsula, the abundance of common ling and blue ling currently appears to be lower than it was in the early years of the fisheries (Lorance and Dupouy, 2001; ICES, 2014). For instance, there is evidence that the biomass of common ling in the North Sea is lower (and probably has been since the late 1990s) than it was in the late 1870s. According to Poulsen et al. (2007), ling abundance was ca. 100-200 million individuals aged 4+ and probably exceeded cod abundances (ca. 3 million individuals aged 3+) in the Skagerrak and in the northeastern North Sea in 1872. There is no current data on common ling abundances in the North Sea but it is probably lower than in 1872, as reflected in declining landings during the late 1990s-early 2000 s 
(Poulsen et al., 2007). Although, in ICES Division 4a (northern North Sea), there was a steady increase in Norwegian longline CPUE values from 2002 until 2016, the trend was negative in 2017 and 2018 (ICES, 2019). It must be considered, however, that these studies normally rely on catch statistics and they assume little change in fishing pressure over time.

From an historical perspective (i.e. since the beginning of the industrial/semi-industrial fisheries), the situation is worrying, particularly for the blue ling in the North Atlantic and the common ling in the Mediterranean Sea. A number of populations of common ling and blue ling, and all Mediterranean ling populations, remain unassessed (Supplementary Table S3); the common ling populations that have been assessed show that they are currently in a good state or fished sustainably - although in the southern North Atlantic areas, landings of this species have decreased sharply from the 1970s onwards; in the Mediterranean, common ling disappeared from the catch in GSA 7 in the 2010s (although it is still being caught sporadically). In the case of blue ling, the signs of overexploitation have emerged now that the spawning stock size is below reference points in ICES Division 3a and subareas 4, 6, 7, 8, 9, 10, 12,14 and depletion of blue ling has been reported in Subarea 2 (Supplementary Table S3). It is important to perform further stock assessments to evaluate the stock's status and be able to develop effective rebuilding plans for stocks that are declared to be overfished.

Blue ling in the North Atlantic is particularly susceptible to rapid local depletion due to its highly aggregating behavior during spawning (Roberts, 2002). Presently, blue ling is considered as 'vulnerable' at the scale of the Northeast Atlantic and 'endangered' in Norwegian waters, and hence is on the Norwegian Red List (Kalas et al., 2010). The situation is also very poor in the Mediterranean for common ling, a species that has disappeared from the catches since the 2010s. According to Svetovidov (1986), and apart from some anecdotal reports of catches in southern Mediterranean waters (Hattour, 2006), the Gulf of Lions is the southern limit of distribution of this cold water species, an area where distribution of the species was already considered rare by this author. Species at the limits of their geographical distribution may face a constrained resources availability that drives them close to their physiological tolerances and capacities (Gaston, 2009). This may be the case of the residual population of common ling in the Mediterranean, where the limiting environmental conditions may have intensified the impact of fishing on this population. Regular catches of large common ling made by longliners in deep waters of Cape Creus (southern Gulf of Lions, GSA7; Fig. 8-left) ceased in the 1990s and no longer appeared regularly in the catch in the 2010s (Lloret, 2017). Although this species has probably not completely disappeared in the northwestern Mediterranean - two individuals weighing 6.1 kg (Fig. 8-right) and 7.0 $\mathrm{kg}$ were landed in 2017 and 2019, respectively, in two fishing ports in the north of Catalonia, and two individuals weighing 1.5 and $13.5 \mathrm{~kg}$ were landed in 2015 in a fishing port in the north of the Valencian Community (Kersting and Azzurro, 2019) - current indications suggest that this species faces a high risk of regional extinction. Common ling presently appears in the IUCN Red List-Mediterranean assessment as 'Data Deficient'; it is a clear example of the declining populations of long-lived species in the Mediterranean (Maynou et al., 2011).

Overall, the analyses of the health of Molva populations in the Northeastern Atlantic and the 
Mediterranean, together with the analysis of abundances suggest that only some populations located in the North Atlantic, such as those near Iceland may be able to rebuild. In contrast, there may be serious problems when it comes to rebuilding the populations in the southern waters of the North Atlantic and the Mediterranean. The differences in these two situations may be attributed not only to the activity of fisheries but also to sea warming, which may represent an additional and increasing threat. Existing information in most North Atlantic and western Mediterranean regions show that not only the surface layers are experiencing rapid warming, but benthic temperatures in many regions are also increasing, including the deep waters at depths below $500 \mathrm{~m}$ (Kavanaugh et al., 2017; Bindoff et al., 2019; VargasYáñez et al., 2017). It should be noted that, based on the ICES Report on Ocean Climate 2017 in the North Atlantic (González-Pola et al., 2018) and the study from Vargas-Yáñez et al. (2017) in the western Mediterranean, the only areas considered in our study that have not experienced sea warming are the northern Icelandic waters at depths of between 50 and $150 \mathrm{~m}$, where no trend was observed in the period 1950-2016, and the Iceland Basin, where a downward trend in water temperature at depths of between 0 and $500 \mathrm{~m}$ was observed in the period 1998-2016 (Supplementary Table S4). The overall warming is evident in all layers of the southern areas of the North Atlantic, for example, in the Bay of Biscay (ICES subareas 8 and 9) 1994-2016, at depth layers of 300-600 m and 600-1000 m, as well as in the western Mediterranean (GSAs 5, 6 and 7) between 75 and $2500 \mathrm{~m}$ in the period 1992-2016 (Supplementary Table S4). Therefore, sea warming may affect both the early and adult life stages of Molva species. Water temperature may play a bigger role in the status of some Molva populations inhabiting in the southernmost ranges of their distribution (where sea water temperatures are the highest), such as those inhabiting the Mediterranean Sea (Lloret et al., 2015). Mediterranean ling inhabiting the waters of the northwestern Mediterranean spawn in the colder, winter months from November to February (Miret and Vera, 2011), whereas in North Atlantic waters, common ling spawn from March to June and blue ling spawn between February and July (Engas, 1983, Bergstand and Hareide, 1996; Magnússon et al., 1997; Munk and Nielsen, 2005). The effects of sea warming may therefore have a greater impact on the reproduction of the southern populations of Molva species that appear to rely more on colder winter waters for reproduction. On the other hand, in some northern areas of the North Atlantic, Molva species could actually benefit from sea warming: having previously been absent in Greenland waters, landings of common ling were reported in the area during the period of warming from 1920 onwards (Brander, 2003). Although adults of Molva species live close to the bottom, the limited information available suggests that eggs, larvae and small juveniles can be found in the surface layers as well as close to the bottom. According to a review of the literature made by Sundby et al. (2017), during the warm period of the 1940s, common ling eggs were observed in shallow waters of the Oslo Fjord, but larvae were also observed in deep waters in various locations in Skagerrak and in the Norwegian Trench. Munk and Nielsen (2005) indicated that the eggs of common ling are spawned close to the bottom. Blue ling has been reported to spawn in deep waters, for example in the shelf break off the Hebrides and Faroe Islands and in the Norwegian Trench.

Due to data constraints, the condition analyses carried out in this study are not exhaustive and therefore future studies should consider gathering more accurate condition indices, such as the hepatosomatic index and the lipid content in the liver. Indeed, since these species seem to store most of 
their energy reserves (the lipid content) in their liver, this may be a better indicator of physical condition in Molva species. Furthermore, the low R squared values of the Kn models suggest that other factors, apart from year and area, may play a role in the variation of the condition index of common ling and blue ling in the North Atlantic, and therefore further studies should be conducted in support of rebuilding strategies for these deep water species, including genetic analyses to better define the stocks. Furthermore, it is well known that the oceans have not warmed uniformly in space or time (Harrison and Carson, 2007; Hakkinen, 2016, González-Pola et al., 2018; Bindoff et al., 2019). Further study is needed into the differences in the vertical and horizontal patterns of sea warming across the North Atlantic and Mediterranean in order to understand the particular effects of sea warming on each Molva population.

Our results support the idea that management plans need to be implemented to improve the status of many populations of Molva species, particularly in southern European waters. These measures should be area-specific; for example, to the west of the British Isles and around Iceland, management by TACs and more protection of spawning aggregations seem to have been efficient in enabling some blue ling populations to rebuild. In contrast, in Norwegian waters, although direct targeting of blue ling has been forbidden since 2009, and a 10 percent by-catch limit is in place (Helle et al., 2018), these regulations seem to have been insufficient for the recovery of the Norwegian blue ling population (ICES 2019). Finally, despite the poor condition of many Molva populations in the North Atlantic and the Mediterranean, the European Council Regulation (EU) 2018/2025 of 17 December 2018, does not cover any of the three Molva species. Appropriate local management actions are needed to avoid the depletion of Molva populations, particularly in southern European waters including the Mediterranean, and to rebuild Molva populations to levels where they can sustain fisheries. The poor condition of a large number of Molva populations in the Northeast Atlantic and Mediterranean is an indication of how other deep-water fish populations may also be seriously at risk of depletion. Further rises in sea temperatures are expected in the North Atlantic and the Mediterranean (Bindoff et al., 2019) which, in turn, is likely to increase the impact (in addition to the effects of fishing) on Molva populations in European waters.

\section{ACKNOWLEDGEMENTS}

This study was financed in part by ES07 - EEA Grant (Ref. 007-ABELIM-2014B) and the Abertis Foundation (Project Ref. 39/10). The authors would like to thank Porsteinn Sigurðsson and Antonio Esteban and other scientists in charge of surveys carried out by various research institutes in the North Atlantic and Mediterranean for providing data for the analyses of condition; we also thank Cristina Miret and Laura Vera for providing data on reproduction and parasitism in the north-western Mediterranean. Finally, we would also like to thank the two anonymous referees for their detailed revision of the manuscript.

\section{AUTHOR CONTRIBUTIONS}

J. LL. designed the research and wrote the text; A. S. contributed to the analysis of data and to writing the manuscript; the rest of coauthors provided expert advice and also contributed to writing the manuscript.

\section{References}


AAVV (2017). MEDITS Handbook, Version nr. 9. MEDITS Working Group, 106 pp. http://www.sibm.it/MEDITS\%202011/principaledownload.htm

Bailey, D. M., Collins, M. A., Gordon, J. D. M., Zuur, A. F. \& Priede, I. G. (2009) Long-Term Changes in Deep-Water Fish Populations in the Northeast Atlantic: A Deeper Reaching Effect of Fisheries? Proceedings of the Royal Society B: Biological Sciences 276, 1965-1969.

Basson, M., Gordon, J. D. M., Large, P., Lorance, P., Pope, J. \& Rackham, B. (2001) The Effects of Fishing on Deep-Water Fish Species to the West of Britain, Final Report for Joint Nature Conservation Committee (F90-01-216). 1-150.

Bates, A. E., Pecl, G. T., Frusher, S., Hobday, A. J., Wernberg, T., Smale, D. A., Sunday, J. M., Hill, N. A., Dulvy, N. K., Colwell, R. K., et al. (2014) Defining and Observing Stages of Climate-Mediated Range Shifts in Marine Systems. Global Environmental Change 26, 27-38.

Bergstad, O. A. \& Hareide, N. . (1996) Ling, Blue ling and Tusk of the North-East Atlantic. Fisehn of Havet rapport 15.

Bindoff, N.L., Cheung, W.W.L. Kairo, J.G. Arístegui, J. Guinder, V.A. Hallberg, R. et al. (2019). Changing Ocean, Marine Ecosystems, and Dependent Communities. In: IPCC Special Report on the Ocean and Cryosphere in a Changing Climate (Pörtner, H.O, Roberts, D.C., Masson-Delmotte, V., Zhai, P., Tignor, P. et al. (eds.). IPCC Switzerland. https://www.ipcc.ch/

Brander, K., Blom, G., Birges, M. F., Erzini, K., Henderson, G., MacKenzie, B. R., Mendes, H., Ribeiro, J., Santos, A. M. P. \& Toresen, R. (2003) Changes in Fish Distribution in the Eastern North Atlantic: Are We Seeing a Coherent Response to Changing Temperature? ICES Marine Science Symposia 219, 261-270.

Burnham, K. P., Anderson, D. R. \& Huyvaert, K. P. (2011) AIC Model Selection and Multimodel Inference in Behavioral Ecology: Some Background, Observations, and Comparisons. Behavioral Ecology and Sociobiology 65, 23-35.

Carbonara, P., Intini, S., Modugno, E., Maratiradonna, F., Spedicato, M. T., Lembo, G., Zupa, W. \& Carnevali, O. (2015) Reproductive Biology Characteristics of Red Mullet (Mullus Barbatus L., 1758) in Southern Adriatic Sea and Management Implications. Aquatic Living Resources 28, 21-31.

Carbonara, P., Porcu, C., Donnaloia, M., Pesci, P., Sion, L., Spedicato, M. T., Zupa, W., Vitale, F. \& Follesa, M. C. (2019) The Spawning Strategy of European Hake (Merluccius Merluccius, L. 1758) across the Western and Central Mediterranean Sea. Fisheries Research 219, 1-13.

Clarke, M. W., Kelly, C. J., Connolly, P. L. \& Molloy, J. P. (2003) A Life History Approach to the Assessment and Management of Deepwater Fisheries in the Northeast Atlantic. Journal of Northwest Atlantic Fishery Science 31, 401-411. 
Domínguez-Petit, R., Saborido-Rey, F. \& Medina, I. (2010) Changes of Proximate Composition, Energy Storage and Condition of European Hake (Merluccius Merluccius, L. 1758) through the Spawning Season. Fisheries Research 104, 73-82.

Engås, (1983). Betydningen av ulike redskapsfaktorer i garnfisket etter blålange (Molva dipterygia Pennant 1784). Universitetet i bergen, Institutt for fiskeribiologi. Hovedfagsoppgave i fiskeribiologi, høsten 1983, 73pp.

Ferrer-Maza, D., Lloret, J., Muñoz, M., Faliex, E., Vila, S. \& Sasal, P. (2014) Parasitism, Condition and Reproduction of the European Hake (Merluccius Merluccius) in the Northwestern Mediterranean Sea. ICES Journal of Marine Science 71, 1088-1099.

Gaston, K. (2009) Geographic Range Limits of Species. Proceedings of the Royal Society B: Biological Sciences 276, 1391-1393.

Genner, M. J., Sims, D. W., Southward, A. J., Budd, G. C., Masterson, P., Mchugh, M., Rendle, P., Southall, E. J., Wearmouth, V. J. \& Hawkins, S. J. (2010) Body Size-Dependent Responses of a Marine Fish Assemblage to Climate Change and Fishing over a Century-Long Scale. Global Change Biology 16, 517527.

González-Pola, C., Larsen, K. M. H., Fratantoni, P., and Beszczynska-Möller, A. (Eds). (2018). ICES Report on Ocean Climate 2017. ICES Cooperative Research Report No. 345. 119 pp. http://doi.org/10.17895/ices.pub.4625

Hakkinen, S. (2016). Warming of the Global Ocean: Spatial Structure and Water-Mass Trends. Journal of Climate 29, 4949-4963

Hare J. A., \& Kane J. (2012). Zooplankton of the Gulf of Maine-A changing perspective. In Advancing an ecosystem approach in the Gulf of Maine (Vol. 79, pp. 115-137). Bethesda, MD: American Fisheries Society Symposium.

Harrison, D. E., \& Carson, M. (2007). Is the World Ocean warming? Upper-ocean temperature trends: 1950-2000. Journal of Physical Oceanography 37, 174-187.

Hattour, A. (2006) First Record of a Ling Fish Molva molva (Linnaeus, 1758) in Septentrional Water of Tunisia. Bulletin de I'Institut National des Sciences et Technologies de la Mer 33, 131-132.

Helle, K., Quintela Sanches, M. \& Johansen, T. (2018) Blålangegenetikk- Genetiske Undersøkelser Av Blålange Langs Eggakanten Og i Utvalgte Fjorder (Genetical Investigations of Blue ling along Eggakanten and in Selected Fjords) Rapport Fra Havforskningen (in Norwegian).

ICES. (2014) Report of the Working Group on the Biology and Assessment of Deep-Sea Fisheries 
Resources (WGDEEP), 4-11 April 2014, Copenhagen, Denmark.

ICES. (2015) Report of the Working Group on Biology and Assessment of Deep-Sea Fisheries Resources (WGDEEP), 20-27 March 2015, Copenhagen, Denmark. ICES. In ICES CM 2015/ACOM:17 p. 738.

ICES. (2019) Working Group on the Biology and Assessment of Deep-Sea Fisheries Resources (WGDEEP). ICES Scientific Reports 1, 988.

IUCN (2004). The Mediterranean deep-sea ecosystems: an overview of their diversity, structure, functioning and anthropogenic impacts, with a proposal for their conservation. Tudela, S. and Simard, F (eds). $125 \mathrm{p}$

Kålås, J. A., Henriksen, S., Skjelseth, S. \& Viken, Å. E. (2010) Environmental Conditions and Impacts for Red List Species. Norwegian Biodiversity Information Centre, Norway.

Kavanaugh M. T., Rheuban J. E., Luis K. M. A., \& Doney S. C. (2017). Thirty-three years of ocean benthic warming along the U.S. Northeast Continental Shelf and Slope: Patterns, drivers, and ecological consequences. Journal of Geophysical Research: Oceans, 122, 9399-9414.

Kersting, D.K., \& Azzurro, E. (2019). Captures of Molva molva (Linnaeus, 1758) still hapen in NW Mediterranean waters. Acta Adriatica 60(1), 103-106

Koslow, J. A., Boehlert, G. W., Gordon, J. D. M., Haedrich, R. L., Lorance, P. \& Parin, N. (2000) Continental Slope and Deep-Sea Fisheries: Implications for a Fragile Ecosystem. ICES Journal of Marine Science 57, 548-557.

Large, P. A., Hammer, C., Bergstad, O. A., Gordon, J. . D. M. \& Lorance, P. (2003) Deep-Water Fisheries of the Northeast Atlantic: II Assessment and Management Approaches. Journal Northwest Atlantic Fisheries Science 31, 151-163.

Large, P. A., Diez, G., Drewery, J., Laurans, M., Pilling, G. M., Reid, D. G., Reinert, J., South, A. B. \& Vinnichenko, V. I. (2010) Spatial and Temporal Distribution of Spawning Aggregations of Blue ling (Molva Dypterygia) West and Northwest of the British Isles. ICES Journal of Marine Science 67, 494-501.

Lloret, J. (2017). Monitoring of artisanal fisheries in the Natural Park of Cape Creus. Technical report Govt. of Catalonia. 53 pp.

Lloret, J., Faliex, E., Shulman, G. E., Raga, J. -A., Sasal, P., Muñoz, M., Casadevall, M., Ahuir-Baraja, A. E., Montero, F. E., Repullés-Albelda, A., et al. (2012) Fish Health and Fisheries, Implications for Stock Assessment and Management: The Mediterranean Example. Reviews in Fisheries Science 20, 165-180.

Lloret, J., Shulman, G. \& Love, R. M. (2014) Condition and Health Indicators of Exploited Marine Fishes. 
West Sussex, UK: Wiley Blackwell.

Lloret, J., Sabatés, A., Muñoz, M., Demestre, M., Solé, I., Font, T., Casadevall, M., Martín, P. \& Gómez, S. (2015) How a Multidisciplinary Approach Involving Ethnoecology, Biology and Fisheries Can Help Explain the Spatio-Temporal Changes in Marine Fish Abundance Resulting from Climate Change. Global Ecology and Biogeography 24, 448-461.

Lorance, P. \& Dupouy, H. (2001) CPUE abundance indices of the main target species of the French deepwater fishery in ICES Sub-areas V-VI. Fisheries Research 51(2-3), 137-149

Lorance, P., Pawlowski, L. \& Trenkel, V. M. (2010) Standarizing Blue ling Landigs per Unit Effort from Industry Haul-by-Haul Data Using Generalized Additive Model. ICES Journal of Marine Science 67, 16501658.

Magnússon, J. V. (1982). Age, growth and weight of blue ling (Molva dypterygia) in Icelandic waters. ICES C.M 1982/G:22 Demersal Fish Committee. 16 pp.

Maynou, F., Sbrana, M., Sartor, P., Maravelias, C., Kavadas, S., Damalas, D., Cartes, J. E. \& Osio, G. (2011) Estimating Trends of Population Decline in Long-Lived Marine Species in the Mediterranean Sea Based on Fishers' Perceptions. PLOS ONE 6(7), e21818

Mecklenburg, A. Lynghammar, E. Johannesen, I., Byrkjedal, J. S. Christiansen, A. V., Dolgov, O. V., Karamushko, T. A. Mecklenburg, P. R., Møller, D., Mecklenburg, C. W., Lynghammer, A., Johannesen, E., Byrkjedal, I., Christiansen, J. S., et al. (2018) Marine Fishes of the Arctic Region. Akureyri, Iceland. Vol. I.

Miret, C., \& Vera, L. (2011). Efectes del canvi global sobre el gènere Molva. Bsc. research work, University of Girona, 55 pp.

Morato, T., Watson, R., Pitcher, T. \& Pauly, D. (2006) Fishing down the Deep. Fish and Fisheries 7, $24-34$.

Munk P., and Nielsen J.G. (2005). Eggs and larvae of North Sea fishes. Biofolia, Frederiksberg, Denmark. 215pp.

Nakagawa, S. \& Schielzeth, H. (2013) A General and Simple Method for Obtaining R2 from Generalized Linear Mixed-Effects Models. Methods in Ecology and Evolution 4, 133-142.

Perry, A.L., Low, P.J., Ellis, J.R. et al. (2005). Climate change and distribution shifts in marine fishes. Science 308, 1912-1915.

Petersen, C.G.J. (1890). Om Naturforholdene i Farvandene indenfor Skagen. Drechsel, C.F., 1890. Oversigt over vore Saltvandsfiskerier i Nordsøen og Farvanden indenfor Skagen. Indenrigsministeriet, København, pp. 103-146. 
Petitgas, P., Alheit, J., Peck, M.A. et al. (2012). Anchovy population expansion in the North Sea. Marine Ecology Progress Series 444, 1-13

Poulsen, R. (2007). An Environmental History of North Sea Ling and Cod Fisheries, 1840-1914. Fisheries and Maritime Museum 3, 306.

Poulsen, R. T., Cooper, A. B., Holm, P. \& MacKenzie, B. R. (2007) An Abundance Estimate of Ling (Molva molva) and Cod (Gadus Morhua) in the Skagerrak and the Northeastern North Sea, 1872. Fisheries Research 87, 196-207.

Reinsch, H. H. (1981). Untersuchungen amb Blauleng, Molva dypterygia. Inf. Fischwirtschaft 28(4): 123127 (in German)

Roberts, C. M. (2002) Deep Impact: The Rising Toll of Fishing in the Deep Sea. Trends in Ecology \& Evolution 17, 242-245.

Serrano, A., Sánchez, F., Punzón, A., Velasco, F. \& Olaso, I. (2011). Deep sea megafaunal assemblages off the northern Iberian slope related to environmental factors. Scientia Marina 75(3), 425-437.

Serrat, A., Lloret, J., Frigola-Tepe, X. \& Muñoz, M. (2019) Trade-Offs between Life-History Traits in a Coldwater Fish in the Mediterranean Sea: The Case of Blue Whiting Micromesistius Poutassou. Journal of Fish Biology 95(2), 428-443.

Spedicato, M.T., Massutí, E., Mérigot, B., Tserpes, G., Jadaud, A., \& Relini, G. (2019). The MEDITS trawl survey specifications in an ecosystem approach to fishery management. Scientia Marina 83S1: 9-20.

Sundby, S., Kristiansen, T, Nash, R. \& Johannessen, T. (2017) Dynamic Mapping of North Sea Spawning. Report of the KINO Project. $198 \mathrm{pp}$

Shin, Y.-J., Rochet, M.-J., Jennings, S., Field, J. G. \& Gislason, H. (2005) Using Size-Based Indicators to Evaluate the Ecosystem Effects of Fishing. ICES Journal of Marine Science 62, 384-396.

Trippel, E. ., Kjesbu, O. S. \& Solemdal, P. (1997) Effects of Adult Age and Size Structure on Reproductive Output in Marine Fishes. In Early Life History and Recruitment in Fish populations (Chambers, R. C., Trippel, E. A., eds), pp. 31-62 New York: Chapman \& Hall/CRC.

Vallin, L. \& Nissling, A. (2000) Maternal Effects on Egg Size and Egg Buoyancy of the Baltic Cod, Gadus Morhua; Implications for Stock Structure Effects on Recruitment. Fisheries Research 49(1), 21-37.

Vargas-Yáñez, M., García-Martínez, M.C., Moya, F., Balbín, R., López-Jurado, J.L, et al. (2017). Updating temperature and salinity mean values and trends in the Western Mediterranean: The RADMED project. Progress in Oceanography 157, 27-46. 


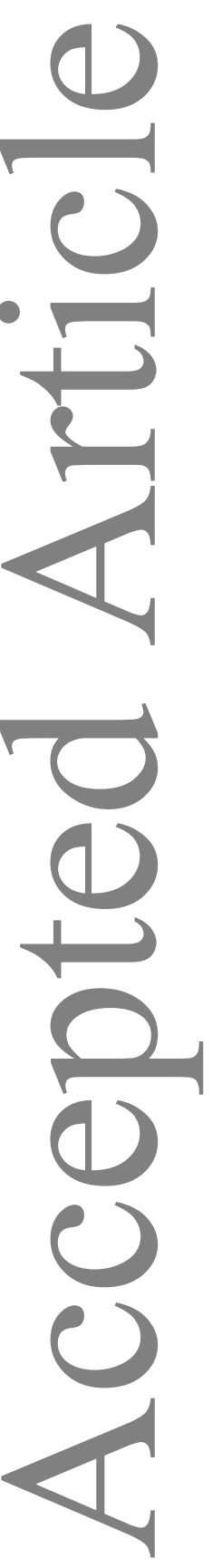

This article is protected by copyright. All rights reserved. 


\section{SUPPORTING INFORMATION}

Additional supporting information (Supplementary tables) is found online in the Supporting Information section at the end of this article. 


\section{Table headings}

Table 1. Time series and number of samples of each species from each subarea. The numbers in bold represent the different ICES (North Atlantic) subareas (1, 4, 5a, 6+7, 14) and GFCM/GSA (Mediterranean) areas (GSAs 5, 6, 7, 8, 9 and 10). For more details on these subareas, see the following section "Le Cren's relative condition index". TL: total length; TW: total weight.

Table 2 Variation of the condition index $(\mathrm{Kn})$ for common ling (M. molva) with year (Y) and North Atlantic ICES subareas $(2,4,5,6+7,14)$ assessed by a generalized linear mixed model. SE: Standard error; SD: standard deviation; AIC: Aikake's Information Criteria; $\mathrm{R}^{2} \mathrm{~m}$ : marginal $\mathrm{R}^{2} ; \mathrm{R}^{2} \mathrm{c}$ : conditional $\mathrm{R}^{2}$.

Table 3. Variation of the condition index (Kn) of blue ling (M. dypterygia) with year (Y) and subareas (2, $4,5,6+7,14)$, assessed by a generalized linear mixed model. SE: Standard error; SD: standard deviation; AIC: Aikake’s Information Criteria; $\mathrm{R}^{2} \mathrm{~m}$ : marginal $\mathrm{R}^{2} ; \mathrm{R}^{2} \mathrm{c}$ : conditional $\mathrm{R}^{2}$. 
Table 1

\begin{tabular}{|c|c|c|c|c|c|c|c|}
\hline & & & & Areas & & & \\
\hline Species & Data & 1 & 4 & $5 a$ & $6 \& 7$ & 14 & \\
\hline Molva dypterygia & & GSA5 & GSA6 & GSA7 & GSA8 & GSA9 & GSA10 \\
\hline
\end{tabular}


Table 2

\begin{tabular}{|c|c|c|c|c|c|c|c|c|c|c|}
\hline $\begin{array}{c}\text { Fixed } \\
\text { effects }\end{array}$ & Estimate & SE & $t$ & $\mathbf{p}$ & Random & Variance & SD & AIC & $R^{2} m$ & $R^{2} \mathbf{c}$ \\
\hline Intercept & -1.92 & 0.04 & -48.97 & $<0.001$ & $Z: M$ & $3.54 \mathrm{E}-04$ & $1.88 \mathrm{E}-02$ & -26196.6 & 0.03 & 0.07 \\
\hline$Y$ & $9.55 \mathrm{E}-04$ & $1.79 \mathrm{E}-05$ & 53.27 & $<0.001$ & Residual & $1.01 \mathrm{E}-02$ & $1.01 \mathrm{E}-01$ & & & \\
\hline 4 & 13.13 & 0.12 & 105.91 & $<0.001$ & & & & & & \\
\hline 5 & -9.88 & 0.23 & -43.28 & $<0.001$ & & & & & & \\
\hline $6 \& 7$ & 0.92 & 0.18 & 5.08 & 0.5 & & & & & & \\
\hline 14 & 19.63 & 0.23 & 84.46 & $<0.001$ & & & & & & \\
\hline$Y: 4$ & $-6.52 E-03$ & $6.14 \mathrm{E}-05$ & -106.18 & $<0.001$ & & & & & & \\
\hline$Y: 5$ & $4.90 \mathrm{E}-03$ & 1.13E-04 & 43.20 & $<0.001$ & & & & & & \\
\hline$Y: 6 \& 7$ & $-4.56 \mathrm{E}-04$ & $9.00 \mathrm{E}-05$ & -5.06 & 0.5 & & & & & & \\
\hline$Y: 14$ & $-9.78 \mathrm{E}-03$ & $1.15 \mathrm{E}-04$ & -84.81 & $<0.001$ & & & & & & \\
\hline
\end{tabular}


Table 3

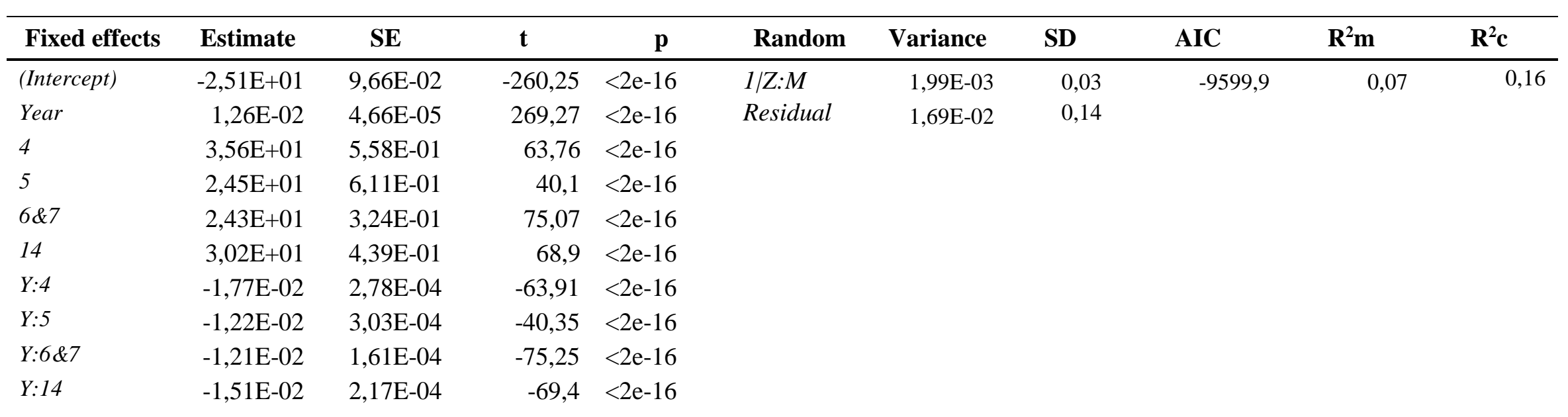




\section{Figure legends}

Figure 1. Map showing the distribution of the three Molva populations considered. Key: black and white fish: common ling (M. molva); grey fish: blue ling (M. dypterygia); black fish: Mediterranean ling (M. macrophthalma). The numbers represent the different ICES (North Atlantic) and GFCM (Mediterranean) subareas (for more details on these subareas, see the following section "Le Cren's relative condition index").

Figure 2 Mean annual condition index (Kn) of common ling (M. molva) in the different Atlantic subareas studied. The colors and shapes represent data for the different ICES subareas 2, 4, 6+7 and 14, and Division 5a, as indicated in the figure. Dotted lines show the temporal trend assessed by linear regression. $y=0.001 \mathrm{x}-1.15 ; \mathrm{R}^{2}=0.01, \mathrm{p}=0.75$ (ICES 2); $\mathrm{y}=-0.005 \mathrm{x}+10.67 ; \mathrm{R}^{2}=0.27, \mathrm{p}=0.03$ (ICES 4); $\mathrm{y}=-0.008 \mathrm{x}+16.56 ; \mathrm{R}^{2}=0.29, \mathrm{p}=0.11$ (ICES 5a); $\mathrm{y}=-0.003 \mathrm{x}+7.69$; $\mathrm{R}^{2}=0.43, \mathrm{p}=0.01$ (ICES 6+7); $\mathrm{y}=-0.008 \mathrm{x}+17.25 ; \mathrm{R}^{2}=0.32, \mathrm{p}=0.07$ (ICES 14).

Figure 3. Mean annual condition index (Kn) of common ling (M. molva) in ICES subarea 4, for the period 1959-2016. The dotted line shows the temporal trend assessed by linear regression. $y=-0.002 x-5.25 ; R^{2}=0.35, p=0.0001$.

Figure 4. Landings (in tons) of common ling (M. molva), blue ling (M. dypterygia) and Mediterranean ling ( $M$. macrophthalma) in the North Atlantic. Landings of common ling were divided into two groups: Ling-South (landings reported by France, Spain and Portugal) and Ling-North (landings reported by Belgium, Channel Islands, Denmark, Faroe Islands, Germany, Iceland, Ireland, Isle of Man, Netherlands, Norway, Poland, Russian Federation, Sweden and United Kingdom. Landings of blue ling reported in ICES subareas 8, 9 and 10 are ascribed to the Mediterranean ling (ICES, 2014)

Figure 5. Mean annual condition index $(\mathrm{Kn})$ of blue ling (M. dypterygia) in the different Atlantic ICES subareas: 2, 4, $6+7$ and 14, and Division 5a (represented by the colors and shapes indicated in the figure). Dotted lines show the temporal trends assessed by linear regression. $y=0.004 x-6.79 ; R^{2}=0.03, p=0.56$ (ICES 2); $y=-0.007 x+14.98 ; R^{2}=0.36$; $\mathrm{p}=0.06$ (ICES 4); $\mathrm{y}=0.001 \mathrm{x}+0.63 ; \mathrm{R}^{2}=0.01, \mathrm{p}=0.56$ (ICES 5a); $\mathrm{y}=-0.001 \mathrm{x}+2.62 ; \mathrm{R}^{2}=0.02 \mathrm{p}=0.67$ (ICES 6,7); $\mathrm{y}=-$ $0.001+4.15 ; \mathrm{R}^{2}=0.05, \mathrm{p}=0.20$ (ICES 14).

Figure 6. Trends in average weights of Mediterranean ling (M. macrophthalma) in the Mediterranean GFCM subareas: GSAs 5, 6, 7, 8, 9 and 10. North Atlantic data is not represented because there are only three years of data. Dotted lines show the temporal trend assessed by linear regressions: $y=0.961 x+69.48 ; R^{2}=0.01, p=0.76$ (GSA 5); $\mathrm{y}=0.47 \mathrm{x}+101.05 ; \mathrm{R}^{2}=0.01 ; \mathrm{p}=0.90\left(\right.$ GSA 6) $\mathrm{y}=-15.29 \mathrm{x}+433.14 ; \mathrm{R}^{2}=0.28 ; \mathrm{p}=0.01$ (GSA 7); $\mathrm{y}=-17.39 \mathrm{x}+673.88$; $\mathrm{R}^{2}=0.03 ; \mathrm{p}=0.48$ (GSA 8); $\mathrm{y}=-7.29 \mathrm{x}+267.23 ; \mathrm{R}^{2}=0.09 ; \mathrm{p}=0.15$ (GSA 9); $\mathrm{y}=-3.58 \mathrm{x}+202.01 ; \mathrm{R}^{2}=0.02 ; \mathrm{p}=0.56$ (GSA 10)

Figure 7. Hepatosomatic (HSI) and gonadosomatic (GSI) indices and prevalence of parasites (\% parasites) during the 
reproductive cycle of Mediterranean ling (M. macrophthalma) in Mediterranean GSAs 6/7. Maturity stages: 1immature, 2- maturing, 3- spawning capable, 4- actively spawning, 5-Post-spawning, and 6- regenerating.

Figure 8 Left: A large example of common ling, M. molva (known as "cod's tongue" in the local language), which used to be caught regularly by longliners in the early 1980s in deep waters off Cape Creus (southern Gulf of Lion, GSA7). Right: a now rare landing of a large common ling, caught in 2017 by a trawler in deep waters in the Gulf of Lion. 


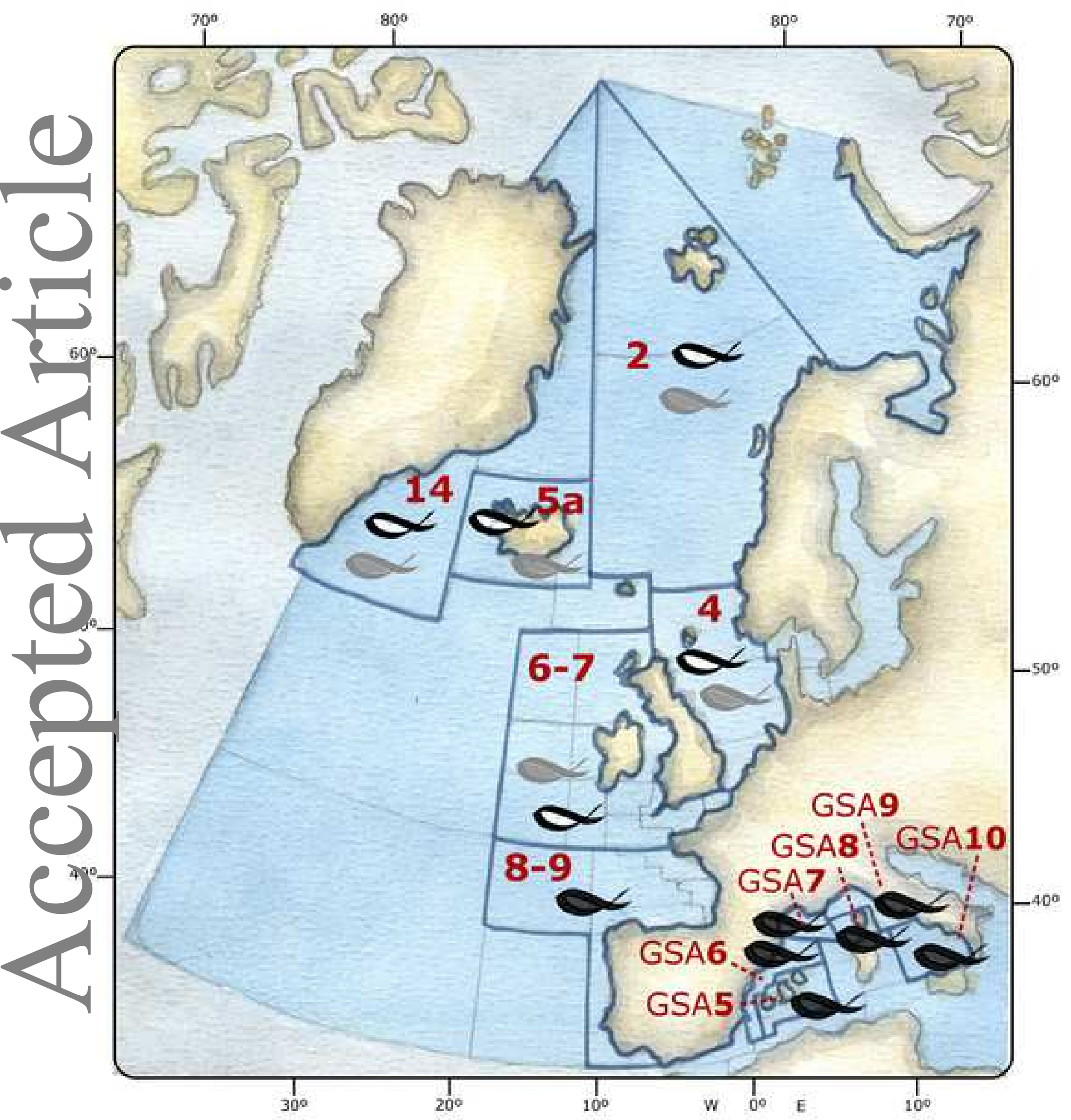




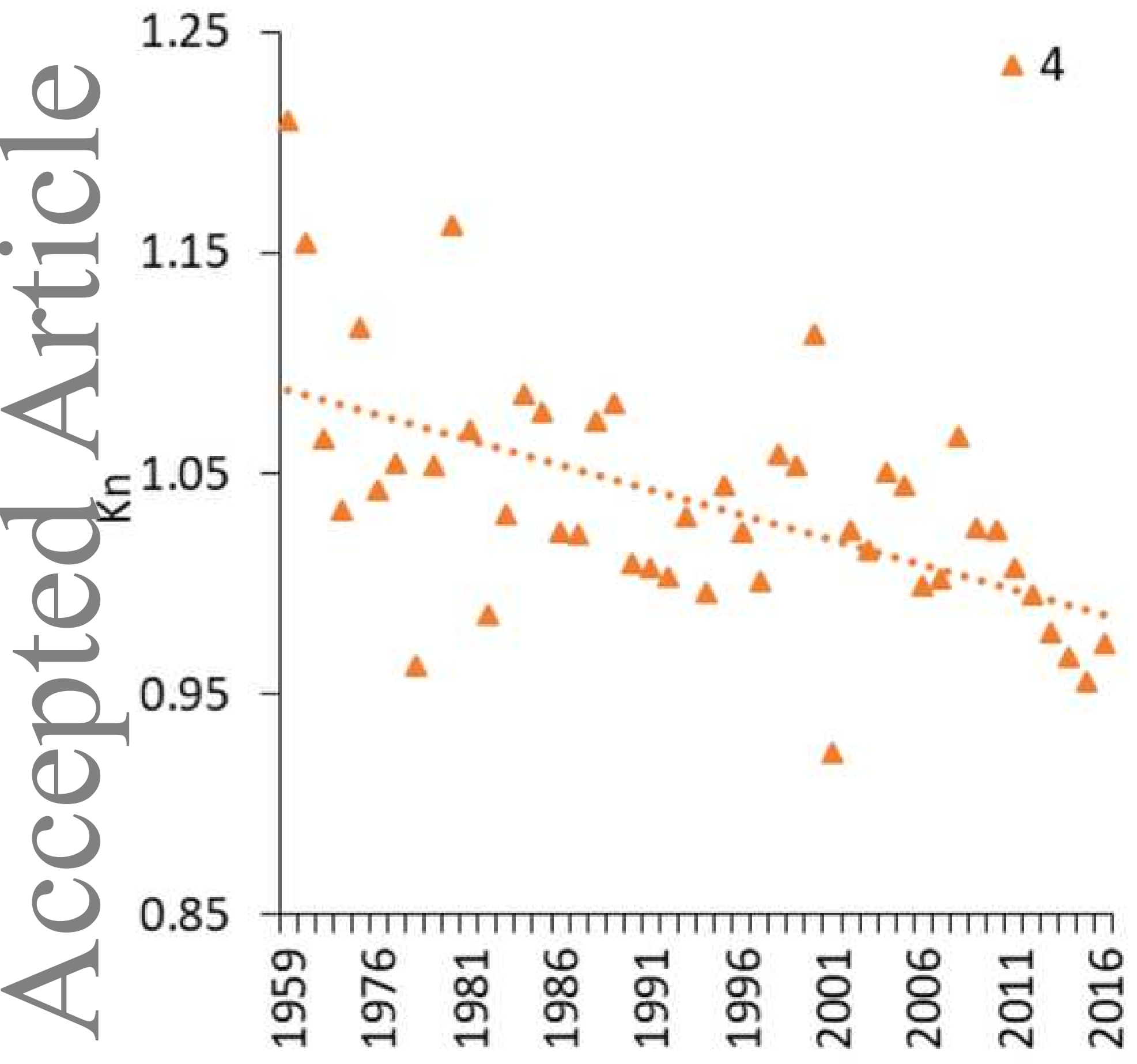



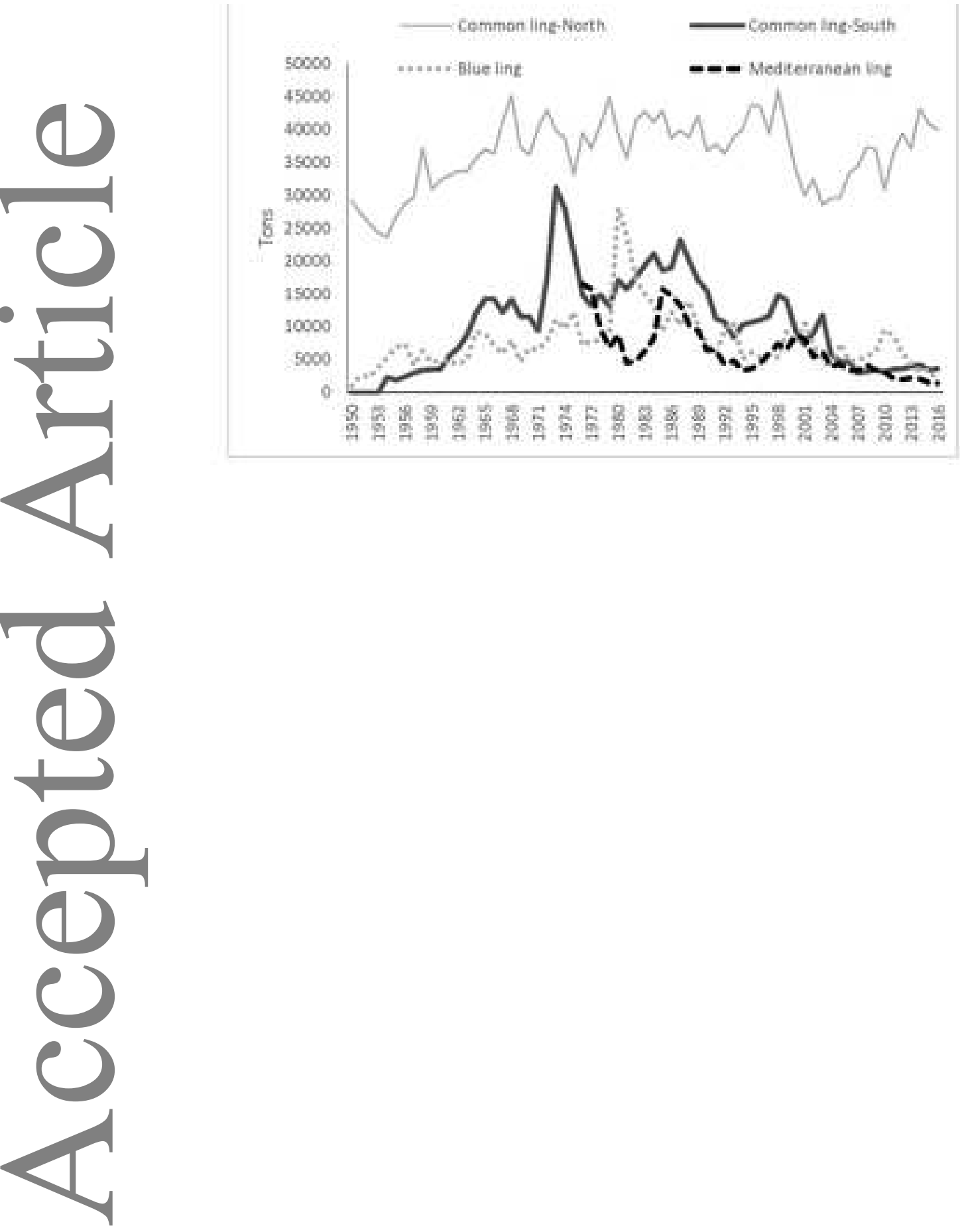


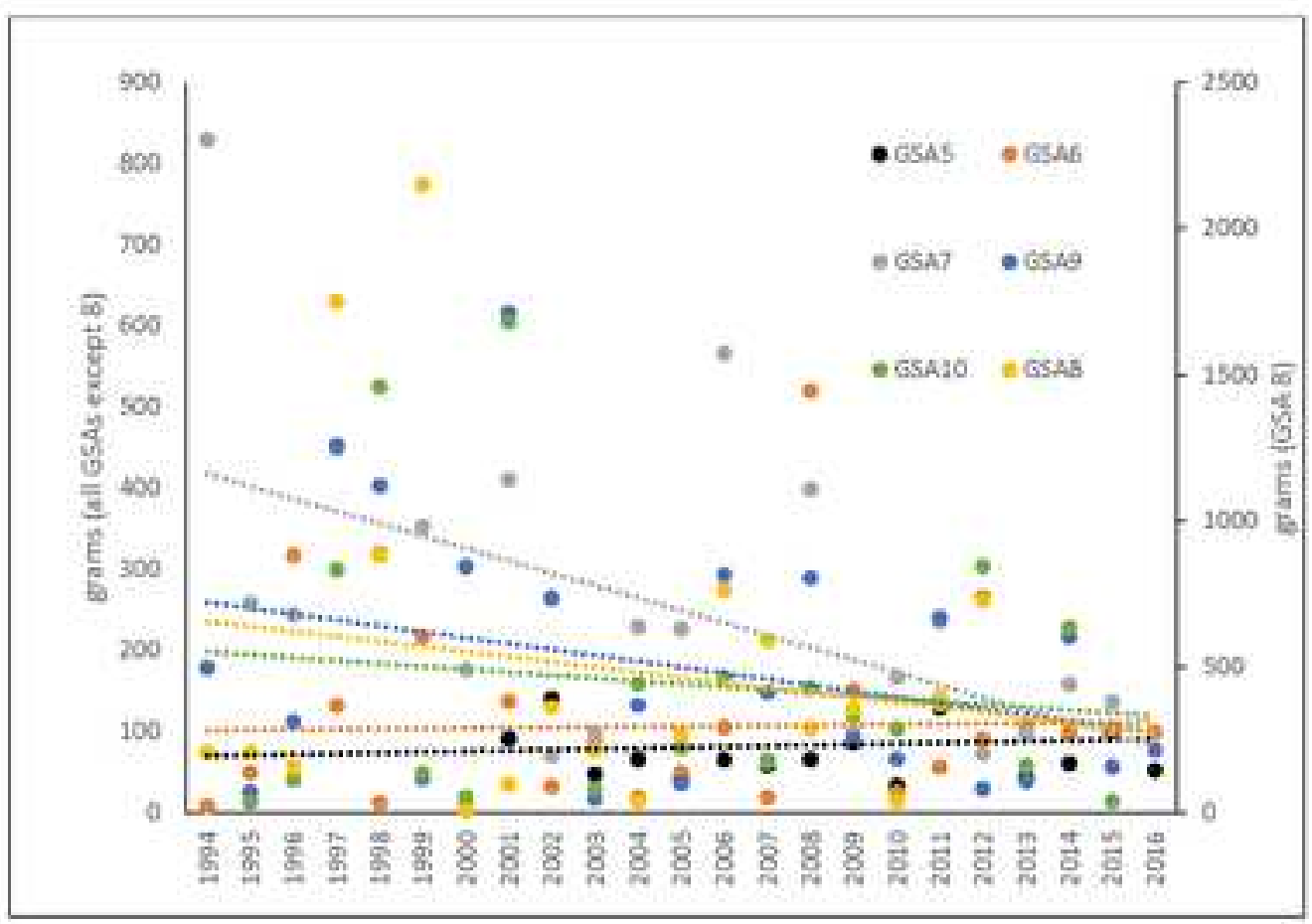




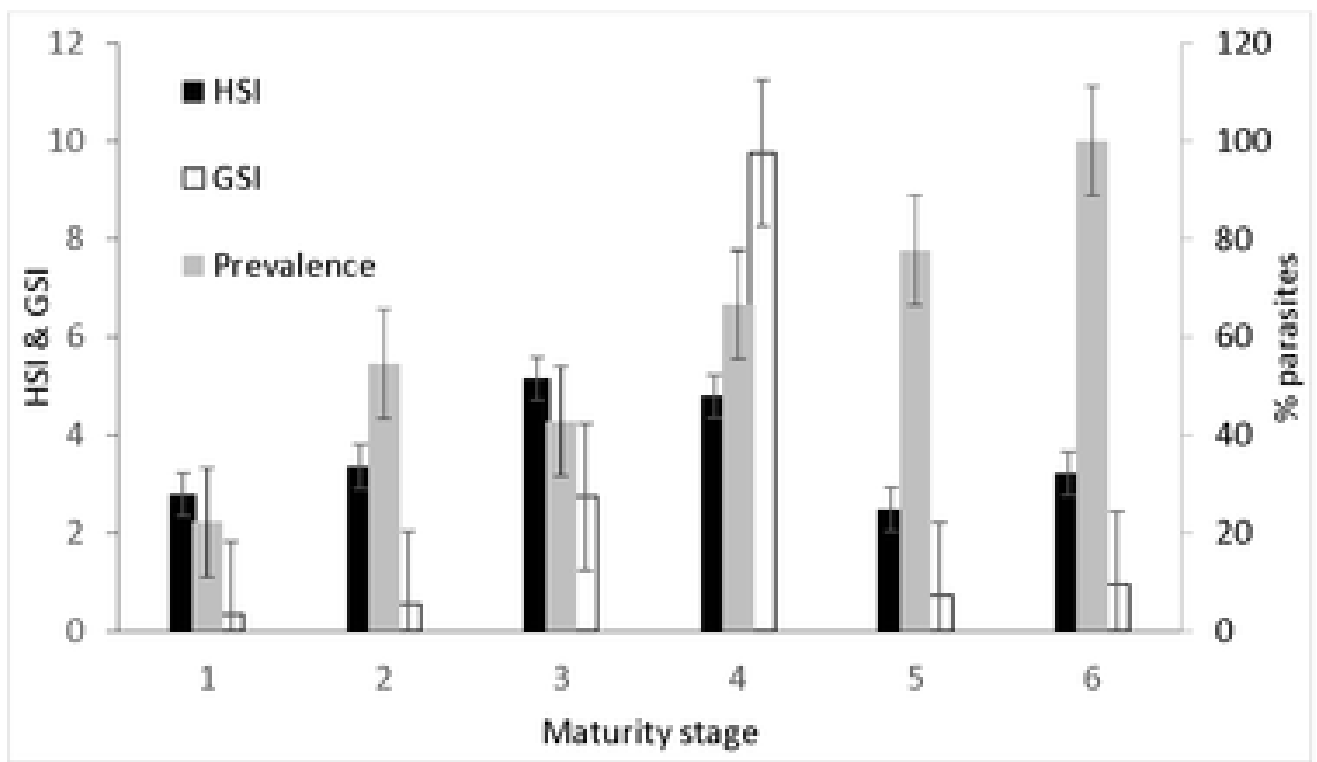




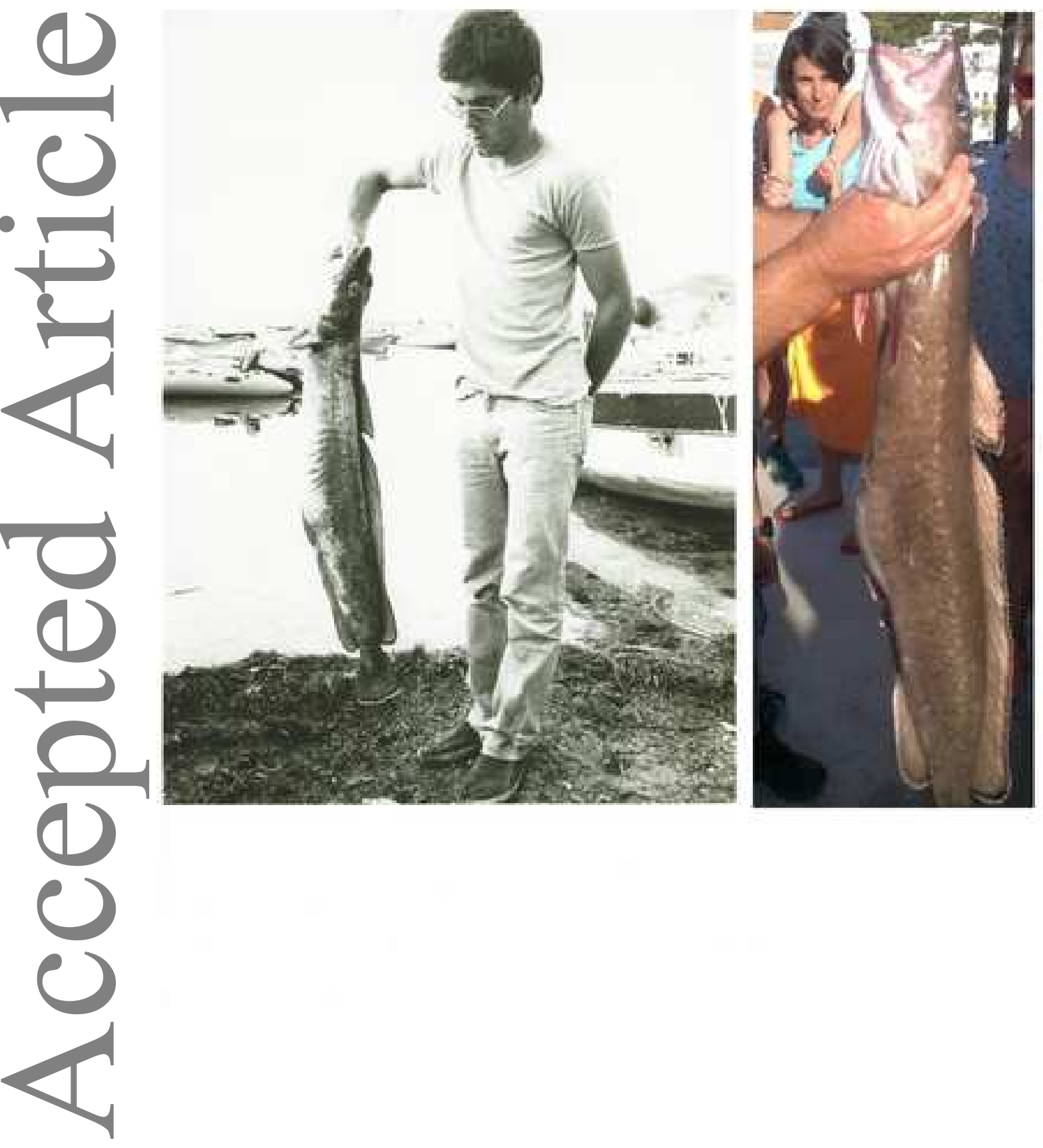

